\title{
Religious involvement of University of Pretoria campus students. Results of an enquiry
}

\author{
Prof J J (Dons) Kritzinger \\ (Emeritus at University of Pretoria)
}

\section{ABSTRACT \\ Religious involvement of University of Pretoria campus students. Results of an enquiry}

In a large sample of full-time University of Pretoria main campus students it was found that a very high percentage of all the students reported an affiliation to religious bodies. They also generally regarded themselves as religious. Many also regularly took part in the religious programmes. Quite a rosy statistical picture could be drawn. The one worrying result is the chasm which shows between what the students regard as their religious organisation's views on certain moral issues, on the one hand, and their own lifestyles, on the other.

\section{BACKGROUND TO THE STUDY}

\subsection{Start of the process}

The University of Pretoria - as is the case with tertiary institutions everywhere - is transforming on many levels. The student body of this erstwhile White Afrikaans University was only 69\% White in 2001, (down from $75 \%$ in 1999), and since then the inflow was largely from the nontraditional sector, and the minority have Afrikaans as their mother tongue. Traditionally the religious care of the students was simple, as their affiliation was largely homogeneous. The demographic changes certainly had an impact on the traditional position of the Afrikaans churches in particular, religion in general, and also the religious care of the students on campus.

A group of students approached the Dean of Student Affairs. They had the impression that many of their fellow students - especially the Black students - were not involved in the religious activities in and around the campus. They were concerned about this perceived lack of religious care, and wondered whether the various role players - even the University - should be doing more. Were there maybe stumbling blocks - unknown to the religious organisations and the University administration - that interfered with the religious integration of these students? 
That these questions were originating from certain traditional circles is not the point. The Dean of Students (correctly) regarded them as a matter not in the first instance for the University to attend to, but rather for the different religious organisations serving the students. However, he also realised that it touched on an important aspect of the students' well being on campus. So he decided to contact the Faculty of Theology in this regard. Could they conduct an enquiry? Was the impression of the said students correct? And if correct, what could be the reasons for the lack of involvement? And what could be done about it?

The Faculty asked Prof J J Kritzinger to lead the research. A small steering committee was formed with representatives from the office of the Dean of Student Affairs, the Forum for the Ministry to Students, and the Students Representative Council. This committee proceeded to plan the research with Prof Kritzinger. He involved senior students as assistants.

\subsection{What was the research problem?}

What is the situation on campus regarding the religious care of students? How involved are the students in religious life? What are the reasons why they are (or are not) involved with religious organisations? Do the students encounter any obstructions hindering them to give expression to their religious beliefs? Are there any internal or external structural problems inhibiting the different religious organisations to effectively attend to the needs of the students? In which ways could the University facilitate a more satisfactory situation?

These questions are all related. What seemed to be necessary was the development of a profile of student religious involvement and needs, and an enquiry into their and other role players's perceptions in this regard. It would also amount to an interesting case study that could serve as an indication of the impact of the continuing secularization in society.

The prime goal of the study was thus to provide the relevant people in the university environment (i.e. the management, the student leadership, and the leaders in the religious communities) with a more qualitative profile of the religious needs and involvement of the student body. They could then act on it according to their different mandates to ensure the optimal well being of the students.

Statistically speaking, the religious affiliation of students is known. Although the students are free to withhold information in this regard, the 
registration forms contain a question on religious affiliation. The table for 2001 is given below (Table 1).

Table 1: Religious Affiliation of UP students, 2001

\begin{tabular}{|c|c|c|c|c|c|c|c|c|}
\hline \multirow[t]{2}{*}{$\begin{array}{l}\text { RELIGIOUS } \\
\text { AFFILIATION }\end{array}$} & \multicolumn{2}{|c|}{$\begin{array}{l}\text { NEW } \\
\text { STUDENTS }\end{array}$} & \multicolumn{2}{|c|}{$\begin{array}{l}\text { ALL UNDER- } \\
\text { GRADUATES }\end{array}$} & \multicolumn{2}{|c|}{$\begin{array}{l}\text { ALL POST- } \\
\text { GRADS }\end{array}$} & \multicolumn{2}{|c|}{ TOTAL } \\
\hline & $\mathbf{N}$ & $\%$ & $\mathbf{N}$ & $\%$ & $\mathbf{N}$ & $\%$ & $\mathbf{N}$ & $\%$ \\
\hline $\begin{array}{l}\text { DUTCH REFORMED } \\
\text { CHURCH }\end{array}$ & 1998 & 38,9 & 7946 & 37,1 & 2987 & 33,5 & 10933 & 36,0 \\
\hline ROMAN CATHOLIC & 367 & 7,1 & 1454 & 6,8 & 685 & 7,7 & 2139 & 7,1 \\
\hline METHODIST & 371 & 7,2 & 1483 & 6,9 & 581 & 6,5 & 2062 & 6,8 \\
\hline NED HERV KERK & 317 & 6,2 & 1182 & 5,5 & 439 & 4,9 & 1621 & 5,3 \\
\hline GEREF KERK & 230 & 4,5 & 971 & 4,5 & 347 & 3,9 & 1318 & 4,3 \\
\hline GERMAN LUTH & 144 & 2,8 & 798 & 3,7 & 410 & 4,6 & 1208 & 4,0 \\
\hline ANGLICAN & 172 & 3,3 & 803 & 3,7 & 404 & 4,5 & 1207 & 4,0 \\
\hline APOST FAITH MISS. & 204 & 4,0 & 805 & 3,8 & 260 & 2,9 & 1065 & 3,5 \\
\hline ZION CHR CHURCH & 81 & 1,6 & 459 & 2,1 & 185 & 2,1 & 644 & 2,1 \\
\hline BAPTIST CHURCH & 81 & 1,6 & 370 & 1,7 & 220 & 2,5 & 590 & 1,9 \\
\hline PRESBYTERIAN & 75 & 1,5 & 265 & 1,2 & 144 & 1,6 & 409 & 1,3 \\
\hline AFR PROTEST KERK & 42 & 0,8 & 139 & 0,6 & 49 & 0,5 & 188 & 0,6 \\
\hline OTHER CHRISTIANS & 133 & 2,6 & 507 & 2,4 & 260 & 2,9 & 767 & 2,5 \\
\hline SUBTOTAL CHR.S & 4215 & 82,0 & 17182 & 80,2 & 6971 & 78,2 & 24153 & 79,6 \\
\hline MUSLIMS & 83 & 1,6 & 294 & 1,4 & 103 & 1,2 & 397 & 1,3 \\
\hline HINDUS & 67 & 1,3 & 272 & 1,3 & 98 & 1,1 & 370 & 1,2 \\
\hline OTHERS, NO INFO & 775 & 15,1 & 3676 & 17,2 & 1747 & 19,6 & 5423 & 17,9 \\
\hline TOTAL: $N$ & 5140 & & 21424 & & 8916 & & 30340 & \\
\hline & & 100,0 & & 100,0 & & 100,0 & & 100,0 \\
\hline
\end{tabular}


A few remarks are in order:

Is it significant that the Christian affiliation specifically (and religious affiliation in general) shows such a decline between under- and post-graduate students? Does it indicate the secularizing influence of the academic atmosphere, or is it the result of the freedom from parental discipline? Although this could be expected it definitely poses a challenge to the religious organisations.

The overall religious affiliation shows a significantly higher percentage for the Christians as the latest national census returns, with around $80 \%$, compared to the national $74 \%$ (Hendriks 2001). The Muslim and Hindu affiliations, however, are about the same at 1,3\% and $1,2 \%$.

\section{METHODOLOGY}

\subsection{Planning}

As the purpose of the study did not include a comparison with other tertiary institutions or contexts we did not do a comprehensive literature search. The idea was to do an independent study which could later be used for follow up studies.

It was clear that the enquiry would have to entail empirical research. A combination of quantitative and qualitative methods had to be used for the analysis. We decided that the main methods would be:

\subsection{The administration of a questionnaire}

It was envisaged that a sample of in the order of 1000 students will be more than sufficient. They would be selected and personally interviewed in order to complete a short questionnaire focused on their perceptions about the value of religion, their involvement with religious organisations, and their views on the availability of religious care.

The sample had to be stratified. We were interested to compare the possible differences between students (a) from the different faculties, (b) with different modes of residence (university hostels or private lodging), (c) the different sexes, (d) the races, and (e) seniority. As far as possible the sample had to be a representation of these groupings as independent variables. It was assumed that it would then also be representative of the different religious persuasions. 
It was also decided that, for the purposes of this present enquiry, only full time students attending classes on the main campus would be targeted, and furthermore only those lodging relatively close to the campus.

The details of the sampling procedures will be described below.

\subsection{Interviews}

Interviews of two kinds would be necessary:

With specific student leaders identified as being able to shed light on the issues raised in the above enquiries.

With people involved in the spiritual nurture of students, in order to (a) gain their impressions about the issues, and (b) test and help interpret the results of the enquiry.

\subsection{The development of the questionnaire}

Over a period of some months (during the year 2000) an instrument was developed. It went through a number of revisions, and then had to be cast in a form that would be viable for the encoding and electronic data capturing in order to enable computer analyses. In this not only the committee, but also the relevant departments of the University, took part.

The idea was to include enough questions that would lead to insight into the student's religious activities and commitments, on the one hand, and his/her subjective feelings and opinions on these matters on the other. Although the questionnaires were strictly anonymous, we required personal data for purposes of comparison.

The questions contained in the questionnaire are shown in Appendix 1.

\subsection{The sample}

The University administration provided a breakdown of the student population (2001) according to (a) the different faculties present on the main campus (we specifically excluded the faculties of Health Sciences, Veterinary Sciences, and even Education, as not being on the main campus), (b) residence, (c) sex, (d) and seniority. The table in Appendix 2 shows this, as well as the planned sample.

Whereas these sample guidelines were kept in mind, the reality of sampling was somewhat different. It was relatively easy to sample the 
hostel students, as it could be done room by room. Those who resided privately, however, had to be interviewed on campus. Here the method was to locate these students in or close to the different faculty buildings. (It was at this stage that we decided not to try and get a representative sample of education students, as their faculty and their activities lately moved off the central campus).

A number of students were recruited and trained to apply the questionnaires. They were paid a nominal fee for every completed questionnaire, but no one was allowed to deal with too many. The first focus was on the hostels, where the sampling was relatively simple. We held a weekly meeting, where the progress was monitored. As soon as the hostel targets were almost reached, the focus shifted to the day students. By continuous monitoring we could balance the sampling to a large extent, and, when the end of year examination period arrived, we could stop the process.

In the end our sample of 747 was more or less representative: 53\% lived in the residences; most of the other $47 \%$ lived in Hatfield or in Sunnyside; the faculties were well represented (see the Table in Appendix 2); $36 \%$ were first year students, and 64\% more senior; Black students were well represented, with $58 \%$ of the sample (Whites $34 \%$ ); females were in the majority (55\%); more than $70 \%$ were 18 to 21 years of age. Only $27 \%$ of the respondents were originally from Pretoria, and of those not from Pretoria 71\% were from outside Gauteng.

\section{GENERAL RESULTS}

\subsection{Involvement}

Are you religious? 91\% said yes. What religion? 88\% said they are Christians, $4 \%$ were African traditionalists, $1,7 \%$ were Hindus, and $0,7 \%$ Muslims. However, (only) 68\% said that they also belonged to a religious organisation on campus, most of these (57\%) to the Student Christian Fellowship ${ }^{1}$. The members regarded themselves as active $(26 \%$ very active, $18 \%$ quite active). $52 \%$ of the sample saw themselves as religiously

1 Whether this organisation was so well represented (among the respondents, or the interviewers) or whether the respondents (most of them Christian) just chose that name as the closest description of their fellowship, is not clear. (It seems as if we have in any case left out the Afrikaans churches' organisations as options.) 
active... and their best friends more or less the same $(26 \%$ saw their friends as more active, and $21 \%$ as less active than themselves).

$60 \%$ of the sample attended church (or its equivalent) the previous week. Of these 58\% attended locally, and 20\% elsewhere in Pretoria. Some $16 \%$ went more than once during that week. Of those who didn't attend that week, $25 \%$ went to church during the previous two weeks, and another $25 \%$ during the past months.

We asked them again: how religious are you? 35\% regarded themselves as very religious, another $58 \%$ as normal or moderate, and only $7 \%$ as skeptical or non-religious. $76 \%$ were perfectly happy with their lives... only $8 \%$ not. About a quarter of the students $(27 \%)$ saw themselves as wholly devoted believers, almost $50 \%$ as normal, and the rest less or not devoted. By far the majority (88\%) believed in God, only $2 \%$ not at all, while $6 \%$ acknowledged doubts. God were seen as a personal Saviour by $78 \%$, as a powerful Spirit by $12 \%$, and the rest as a more impersonal force or a powerful ancestor.

When asked what the student saw as the most important purpose of religion $66 \%$ felt that it is important to acknowledge that there is a God who must be worshipped. Another $23 \%$ found the purpose of religion in giving meaning to life, whereas $8 \%$ found it necessary to provide guidelines for moral behaviour.

Three out of four were satisfied with their religious organisation, and $87 \%$ found it worthwhile to attend church (or the equivalent). Two-thirds of the respondents didn't mention any factors hindering their attendance. When pressed for reasons for non-attendance by far the majority of the students mentioned academic reasons. In order of frequency the other reasons were: the boring services, socials, too academic sermons, and the influence of friends. Only 30\% could think of positive recommendations to make to the religious organisations, of which changes in the format of worship services was the most frequent (84 students). 60 mentioned the introduction of social programmes, 47 more contact with other campuses, and 36 thought that changes in leadership and racial representation would make a difference.

\subsection{Morals}

Three-quarters of the students acknowledged that their religion/ denomination had a moral code that the members were expected to adhere to. We 
tried, therefore, to determine the influence of that religious code on their moral behaviour. We first asked questions on their perceptions about the position of their religion/denomination on certain controversial issues, and then asked them about their own stand or behaviour.

There was quite a dichotomy: for example, although $62 \%$ saw their religion/denomination as against the use of strong liquor, $44 \%$ of the respondents nevertheless drank alcoholic beverages. Although (only) twothirds thought that their religious organisation was against the smoking of tobacco, more than that $(80 \%)$ in any case didn't smoke themselves. Although there was absolutely no doubt that the use of dagga was prohibited by their religion, 5\% nevertheless did it. 42\% saw the smoking of tobacco as a right, and that people should have the freedom to choose for or against it. Another 36\% regarded it as an inadequate action that ends in the degradation of morals. Especially significant were the questions about pre-marital sex: 94\% knew that their church was against this, but $24 \%$ seem to be in any case doing it $(2 \%$ were in gay sexual relations). $63 \%$ were not (at that stage) sexually active, and $16 \%$ regarded the question as too personal to answer.

\section{DISCUSSION AND FURTHER ANALYSIS}

Further analysis brings other important aspects to light. There are differences between the groups.

\subsection{Differences between the racial groups}

The numbers of Coloured and Asian students were small (22 and 32), so one should in general not make sweeping conclusions about those. However, in the case of Black (around 420) and White (in the order of 250) students, differences are sometimes significant. It is interesting to discuss some of these.

While there is no difference in religiosity (in both cases $91 \%$ said that they are religious), $95 \%$ of the White students saw themselves as Christians, and only $89 \%$ of the Blacks. In the last case $6 \%$ declared themselves to be African Traditional Religionists. As could be expected many Asians were Hindus (38\%), Muslims (6\%) and Buddhists (6\%). We must repeat that these were small numbers, and even the $47 \%$ Christians among the Asians should be seen as only an indication. It is significant that (contrary to what could have been expected) a much larger percentage of Black students belonged to a religious organisation on campus than 
White students (43\% over against $14 \%$, while among the Coloured and Asian students this was about a quarter), and that more Black students were very active in the organisation (31\% over against 19\%).

Black attendance at church (that week) was higher than among the White students $(63 \%$ against $55 \%)$, and most $(60 \%)$ of them locally. It does, however, seem as if the White students go more regularly $(29 \%$ of those who missed out that week, went the previous week, over against the $24 \%$ Blacks). About a quarter of both groups haven't been to church for months!

Few Coloureds and Asians regard themselves as very religious, but $36 \%$ of the Blacks and Whites do. Whereas $40 \%$ of the Blacks and Whites are very satisfied with their lives, only $20 \%$ of the Coloureds and Asians feel that way, even if they feel fine. The majority of all the groups regard their religious commitment as normal, and not extreme. Over $80 \%$, almost $90 \%$ believe strongly in God, the majority believe in Him as a personal saviour $(77 \%$ of the Blacks, $85 \%$ of the Whites, $80 \%$ of the Coloureds, and $54 \%$ of the Asians). Among the Blacks a strong second place is taken by their belief in God as a powerful spirit, and among the Asians 21\% see him as a power.

Although the numbers are not significant, it seems as if the Coloured (and Asian) students are less satisfied with the religious organisations than the other groups... only $60 \%$ of the Coloureds (and 53\% of the Asians) are satisfied, compared to the $77 \%$ of the majority groups. Almost $20 \%$ of the Coloured students interviewed didn't regard church attendance as worthwhile.

The majority (more than two-thirds in every case) didn't experience any impediments to taking part in religious activities, even though they would often mention academic pressure as the main reason for not being more active. A third of the Black students (more than the quarter of the Whites) feel that their religious organisations should change in some ways. $70 \%$ of the Blacks, $64 \%$ of the Whites, $48 \%$ of the Coloureds, and $37 \%$ of the Asians thought that the most important purpose of religion was to acknowledge that there is a God who needs to be worshipped. Another $19 \%$ of the Blacks, $26 \%$ of the Whites, $43 \%$ of the Coloureds and $52 \%$ of the Asians (note the order!) saw the main purpose as to give meaning to life. 
Maybe the most significant differences among the groups were in terms of the moral teaching and its effects. It was clear that the Black students came from a more legalistic religious context (than the Whites), or at least that is their perception of their religious oranisations. They saw the use of liquor as prohibited (79\%, over against the $31 \%$ of White students); the smoking of tobacco is equally not allowed (83\%, over against the $37 \%$ in the White community); and the attendance at night clubs are frowned upon (85\% and 39\%). Pre-marital sex is (significantly) condemned in all the communities (Blacks: 94\%, Whites: 96\%, Coloureds: $100 \%$, Asians: 93\%), as is the smoking of dagga and homosexual relations. However, when we enquire about the students' own lifestyle, we find (a) that they allow themselves definitely more freedom, and (b) sometimes disregard the religious advice to a large extent.

$76 \%$ of the White students take alcohol, $57 \%$ of the Coloureds, $41 \%$ of the Asians and $25 \%$ of the Blacks; $37 \%$ of the Asian students, $31 \%$ of Whites, $29 \%$ of the Coloureds, and (only) $11 \%$ of the Blacks smoke tobacco. The smoking of dagga is as high as $13 \%$ among the Asian students, $10 \%$ among the Coloureds, $6 \%$ among the White and 3\% among the Black students.

It is however specifically in the sexual ethic that the students show a disregard for the general religious code of abstinence before marriage. $43 \%$ of the Coloured students, $28 \%$ of the Blacks, $23 \%$ of the Asian and $18 \%$ of the White students are having pre-marital or casual sex. $10 \%$ of the Coloureds and 7\% of the Asians are even homosexually active. (In answering another question only $75 \%$ of the Asian, $64 \%$ of the White, $45 \%$ of the Coloured and $44 \%$ of the Black students gave a clear "no" answer to are you sexually active?)

Especially these last (but also other) issues would be interesting to compare also on other levels: disciplines, seniority, sex, and mode of residence.

\subsection{Faculties}

Apart from finer nuances the main contrasts seem to be between the (few) theological and the law students. As could be expected the theological students are more active in religious matters (96\% against $42 \%)$, but also in organisations ( $76 \%$ very or quite active, compared to $46 \%$ ). As answer to another question $62 \%$ of the theological students saw themselves as very active religiously. $60 \%$ of the law students regarded themselves as normal. 
Also the church attendance is more frequent: $85 \%$ of the theological and $51 \%$ of the law students were in church the previous week, $52 \%$ of the theological students twice. Satisfied with your life? 98\% of the theological students think that life is just fine... 22\% of the law students don't agree... they don't view it so positive. 58\% of the theological students reckon that they are wholly devoted, and only $18 \%$ of the law students.

Practically all have a strong faith in God (85\% of the law students). Not all see God as a personal saviour $(96 \%$ of the theological, but $68 \%$ of the law students). Whereas $80 \%$ of the theological students see the main purpose of religion to bring people to an acknowledgement and worship of God, a good $26 \%$ of the law students see religion as giving meaning to life... more horizontally. Two-thirds of the law students are satisfied with their religious organisation ( $88 \%$ of the theological students are satisfied), and regard it as worthwhile to go to church (82\%), and only few recommend changes (31\%). On the other hand, the theological students are active, are satisfied (88\%), find it worthwhile (88\%), but $42 \%$ have recommendations to make.

It is interesting that on the level of morals - how they perceive the church's stand on certain issues - the theological students are much more open (or is it knowledgeable?) than the law students: $71 \%$ (over against $35 \%$ ) is of opinion that the church allows the use of liquor, 50\% (over against 29\%) thinks that the church allows smoking, and 56\% (against $28 \%$ ) saw the church as not against night clubs per se. All were practically unanimous, however, that the church was against dagga smoking, sex before marriage, and homosexual relations. There was also largely a consensus that the church had a moral code $(84 \%$ and $75 \%)$, and that the members were supposed to adhere to it. Nevertheless, $48 \%$ of the law students, for example, regarded the use of liquor and tobacco as a right where each person had to decide for him/herself (only 16\% of the theological students agreed with this). They had, however, the same views on the unacceptability of these practises: $28 \%$ regarded it as inadequate and leading to a degradation of morals (We didn't pursue the difference between use and misuse). 
As could be expected from the previous, alcohol was used freely by both the theological students $(65 \%)$ and law students $(42 \%)^{2} .19 \%$ of the theological and $23 \%$ of the law students smoked tobacco. But what was the case with those things that they were sure the churches prohibited: dagga smoking, homosexual relations, and pre-marital sex? Here we see the same dichotomy as before: whatever the religious bodies may say, $33 \%$ of the law students ( $8 \%$ of the theological students) were sexually active, 3\% had homosexual relations and 9\% smoked dagga.

How would the sexes, the hostel and other dwellers, and the junior and senior students compare?

\subsection{Junior and senior students}

There are very few differences between the junior and senior students apart from the impression that there is a growth in maturity. On the one hand the senior students seem to be marginally more active and committed to religious activities. Whereas $19 \%$ of the first year students described themselves as very active in religious organisations, $30 \%$ of the seniors were... a significant difference. That could simply be because the seniors are already settled in the University context, and are even fulfilling leadership roles. $37 \%$ of the seniors described themselves as very religious, and only $31 \%$ of the juniors; $30 \%$ see themselves as wholly devoted, over against $21 \%$ of the juniors; $42 \%$ of them are satisfied with their life as it is, against the $33 \%$ of the juniors; the seniors are significantly more satisfied with their religious organisation $(78 \%$ over against the $69 \%$ of the juniors), again quite understandable, and are willing to make some positive proposals; marginally more $(88 \%)$ reckon the worship service as worthwhile, against $86 \%$ of the juniors.

In terms of the ethical issues there are no differences in how they view the church's stand on these things, except on the issue of homosexuality, where the seniors are much more lenient. On the one hand the juniors seem to be taking the freedom of conscience more seriously: $48 \%$ of them (over against the $39 \%$ of the seniors) see the issues regarding the use of alcohol and tobacco as free decisions for the individual... $40 \%$ of

2 It would have been interesting to find out what kind of alcoholic drinks were involved. Would there be different views about beer and strong liquor? The theological students came out as not being legalistic in this case, but what would they say about excessive drinking? 
the seniors regard these as inadequate actions, against the $31 \%$ of the juniors. On the other hand the seniors are consistently more active sexually: $26 \%$ over against $21 \%$ are sexually active, although it is not statistically significant. That can also be expected because of the possibility of more mature (time wise) relations. (As a matter of fact, we didn't ask anything about marriage status... some of the seniors could even be married!).

\subsection{Male and female students}

This is an interesting comparison. Some of the significant differences between the attitudes and lifestyle of the sexes could have been expected, others are surprises.

Firstly. A good $93 \%$ of the lady students saw themselves as religious - not necessarily very religious, but at least normally religious - but only $88 \%$ of the males (difference statistically significant). $91 \%$ of the females were Christians, and $85 \%$ of the males. Although not a larger percentage of the female students were in church the previous week, they seem significantly more regular than the male students... $46 \%$ of those who missed church the previous week went at least once in the previous two weeks (over against the males with $34 \%$ ). $18 \%$ of the males were last in church months ago. Characteristically (?), 44\% of the male students were however very satisfied with their lives, more than the $35 \%$ of the female students, and more $(30 \%$, over against $24 \%)$ of the males also regarded themselves as wholly devoted religiously.

Another significant difference was in the answer to Do you believe in God? $96 \%$ of the female students said: strongly, or as a necessity... and $89 \%$ of the males. $7 \%$ of the males regarded themselves as sceptics or unbelievers. There was also a (statistical) significant difference between their satisfaction with their religious organisation... $81 \%$ of the females, over against $67 \%$ of the males. They also find it more worthwhile to take part in worship services than the males.

The sexes don't differ much in terms of their perceptions of the church's ethical expectations of its members. However, when it comes to conduct there are differences. Less of the female students (22\%) participate in pre-marital sex than the males $(28 \%)$, and they are also less into the smoking of dagga (3\%) than the males (7\%). Although the female students tend to drink less (40\%, over against $49 \%)$, and smoke less $(18 \%$, over against $21 \%$ ) than the males, they feel stronger about it being a 
personal matter for decision (45\%, over against 39\%) than the male students.

\subsection{Hostel students and the rest}

The last possibly relevant contrast which we could highlight is that between the students living in the university hostels and those in all sorts of private lodgings.

Although it at first glance appeared as if the hostel students were more religiously inclined than the rest (93\%, over against $89 \%$, with $38 \%$ regarding themselves as very religious, over against the $31 \%$ of the rest), the statistical tests didn't regard these differences as significant. Nevertheless, the tendency is there. They are definitely and clearly more involved in religious organisations (38\%, compared to $24 \%$ ), although all of them regarded themselves as equally active religiously $(51 \%)$.

$63 \%$ of the hostel students went to church the previous week $(56 \%$ of the others), and another $46 \%$ of those who missed out went in the previous two weeks (compared to the $34 \%$ of the others). This is significant ${ }^{3}$.

The hostel students were significantly more inclined to view God as a personal saviour ( $82 \%$, compared to $74 \%$ ), and also found it more worth their while to attend church (90\%, compared to $84 \%)$. More of them $(69 \%$, over against $61 \%$ ) saw the most important purpose of religion as: to acknowledge that there is a God who needs to be worshipped, while only $5 \%$ (over against $11 \%$ ) saw this purpose as to provide guidelines for moral behaviour.

The hostel dwellers were consistently more conservative in their perception of the church's dislikes of drinking, smoking, night clubs, and homosexual relations, and were equally sure that the church forbade sex before marriage and dagga smoking. They indeed also smoked less $(17 \%$, over against $23 \%)$ and had less homosexual relations (1\%, over against $3 \%)$. When it comes to sexual activities, the differences were real $(55 \%$ negative, compared to $49 \%)^{4}$, even if it was not statistically significant.

3 In an interesting check on the data the question about "where did you attend?" showed an extremely high correlation between the hostel students and "local" attendance. It provides added credibility to the data.

4 Here there may be a discrepancy. When asked do you personally participate in pre-marital sex the yes percentages were 23\% (hostel dwellers) and $26 \%$ (others). When the question was are you sexually active the yes answers were $20 \%$ 


\section{CONCLUSIONS}

A number of conclusions were made from the empirical statistical data, and tested in different discussions. The following are some of the results of the whole process:

1 On the basis of the enquiry it cannot be concluded that there are structural impediments making it difficult for students to continue their religious activities.

No students mentioned anything that could be construed as discriminatory or structural stumbling blocks to their religious expression. The reasons given for inactivity were always personal, with academic pressure most often the reason.

2 On the basis of the enquiry there are not really indications that the (new) Black student body is less religious or less involved in religious activities than the bulk of the (traditional) White students. They rather seem to be even more actively involved.

We recall that a different perception caused the undertaking of the study. Why the misunderstanding? Is there no or too little contact between the races in religious activities? Or does it reflect a difference in perspective $?^{5}$ Representatives of (some) organisations feel a lack of interest.

3 The fact is that it is almost incredible how high the percentages are of the students (a) who regard themselves as religious (mainly Christian), and (b) who say that they are religiously active.

Is it true, or too good to be true? There doesn't seem to be any significant trend of a turning away from religion as result of the process of secularisation. The few indications are seen among the junior, male students, in private lodgings, and more in specific faculties (like Law).

Is this an indication of a nominal (or late) Christendom, rather than post-Christendom? Or is it still the traditional mode of reporting what the student perceives to be the norm? It may be necessary to get (for instance) the church attendance figures as a control over against the reported local

and $23 \%$. However, only $55 \%$ and $49 \%$ respectively said they are not sexually active.

5 Contrary to what the reader may have expected, it was not a group of White students who were worried about the situation. The original group included Black students. 
attendance. It is not necessarily an argument against the students' integrity, but more an enquiry into their perceptions: they may think they are going to church more often than they do; they may think they are more active than they in reality are.

4 There are clear indications that religion matters to the students. They regard their faith in God as important, they are satisfied with their religious organisations, they report a lifestyle of involvement with religious matters. They largely seem to understand the tenets of their faith. We haven't gone deeper as only their feelings, and their reported activities, but it seems as if these should be taken seriously.

What is true, however, is that there is a consistent gap between the students's description of themselves as religious and their active involvement with organised religion, even if it is still high. This concurs with the perceived trend in society that there is a growing number of people who turn away from organised religion, but without necessarily leaving the faith. Has it become a feature here?

5 The main result of this enquiry, however, and which runs like a golden (no, rather a dark) thread through the results, is the discrepancy between faith and practice, dogma and life, dream and reality.

In the results this comes through in all the socio-ethical cases that we touched on: the use of liquor, tobacco, and dagga, and partying in night clubs. However, it is especially in the area of sexual ethics (sex before marriage, and homosexuality) that there is a wide gap between what the students perceived to be the "right" thing to do (according to their religious authorities), and their actual practice. There was very little hesitation among the students about the unacceptability of pre-marital sex (at least in the light of the church or religious dogma), although only $63 \%$ said that they were not (at that stage) sexually active ${ }^{6}$.

Either the ethical demands of the church are out of touch with reality, even mistaken, or the church has very little influence on the lives of its (active) members in areas where it matters. Sexual ethics have these days

6 Here the situation seems to differ somewhat among the racial groups. In answering the question only $75 \%$ of the Asian, $64 \%$ of the White, $45 \%$ of the Coloured and $44 \%$ of the Black students gave a clear "no" answer to are you sexually active? Knowledgeable medical people even regard this percentage as too high. Very few (they say) young people (Blacks especially) are not sexually active. 
acquired extraordinary importance in the context of the HIV/AIDS scourge. Does not even this scare have an influence on the sexual behaviour of the students (who should be well informed regarding the medical aspects of HIV/AIDS)?

Is it a case of group pressure... the student life? Or does this disregard for (religious) authority indicate a far deeper and disturbing malaise in religious (and public) life? Among all the introspection that is currently necessary for religious bodies, this finding should be a pertinent indicator for the need of intensive renewal.

\section{PROPOSALS}

1 There is no reason, on the basis of the results of this study, to propose any structural changes to either the religious institutions or the University management.

2 This somewhat superficial enquiry has in any case confirmed that religious institutions need to re-assess not only their programmes, but the effects of their teaching on their youth membership.

\section{ACKNOWLEDGEMENTS}

The financial assistance of the Vice Principal for this research is hereby acknowledged. He is however not to be held responsible for any of the opinions expressed here.

The professional assistance - in terms of the questionnaire, sample and statistical work regarding this research of the personnel of STATOMET and related departments - is acknowledged.

The research assistance of especially Hettie van Niekerk and Enos Munyai is gratefully acknowledged.

\section{Consulted literature}

Hendriks, J H 2001. Religion in South Africa: Census '96. Chapter 2 in South African Christian Handbook 2001/2. Tyger Valley: CNW Media and Tm. 


\section{APPENDIX 1: THE QUESTIONS ON THE RELIGIOUS NEEDS AND ACTIVITIES OF STUDENTS}

(Only the questions, not the format)

1 Respondent number

2 Card number

A PERSONAL

3 Place of residence? Hostel, Private, Home, Other

4 Suburb? Hatfield, Brooklyn, Muckleneuk, Sunnyside, Arcadia, Lynnwood, Hillcrest, township

5 Faculty? Economics, Human Sciences, Engineering, Natural Sciences, Education, Law, Theology

6 Seniority? First year, senior

7 Racial group? Black, White, Coloured, Indian, Other

8 Gender? Female, Male

9 Age?

10 Are you originally from Pretoria? Yes, No

11 If not from Pretoria, where are you from? Elsewhere in Gauteng, Other province, Outside SA

12 If you are from Pretoria, how long have you lived here? 0-6 months, 7-12 months, 1-3 years, 4-5 years, 6-10 years, longer than 10 years, Since birth

\section{B FORMAL RELIGIOUS ACTIVITIES}

13 Are you religious? Yes, No

14 What is your religious affiliation? Traditional African Religion, Christian, Hindu, Muslim, Buddhist, Jewish, Other (specify), No religious affiliation

15 If your religious orientation is Christian, what is the name of your denomination?

16 Do you belong to any religious association on campus? Yes, No

17 If yes, which organisation do you belong to? Student Christian Movement, Student Christian Fellowship, Campus Crusade, Pentecostal Student Association, Association of Catholic Christian Students (ACTS), Bakti Yoga \& Vegetarian Society, His People, International Church of Christ, Islamic Students' Society, Salt \& Light Christian Fellowship, TACF, Other

18 If you belong to a religious organisation, how actively are you involved? Very, Quite, Moderate, Not really, Not at all, Not applicable

19 Do you consider yourself religiously active? Yes, No, More or less 
20 Is your best friend more / less active than you are? More, Less, Same

21 Did you go to church / synagogue /mosque / temple last week? Yes, No

22 If you did, where? Local, Other in Pretoria, Other town, Not applicable

23 If you did, how many times did you go to church /synagogue / mosque / temple this week? Not at all, Once, Twice, Three times, Not applicable

24 If you did not attend church / synagogue / mosque / temple last week, when did you last go? Previous week, Two weeks ago, Months ago, Long ago, Not applicable

25 How religious are you? Very, Normal, Moderate, Skeptic, Not at all

26 Are you satisfied with your life? Very, Just fine, Sort of, Not really, Not at all

27 Are you a good devotee? Wholly devoted, Normal, Not entirely, Not that much, Not at all

28 Do you believe in God? Strongly, As a necessity, Not always, Sometimes I doubt, Not at all

29 You believe in God as... Personal Saviour, A powerful Spirit, A power, A principle, A powerful ancestor

30 Are you satisfied with the ministry of your religious organisation? Yes, No, Not applicable

31 Do you consider it worth your while to attend church /synagogue / mosque / temple services? Yes, No, Not applicable

32 Is there anything that prevents/hinders you from attending church / synagogue / mosque / temple? Yes, No, Not applicable

33 If there is a problem, which of the following is the most applicable?

Academic pressure (33)

Social dates with your boyfriend/girlfriend (34)

Racial orientation of the religious organisation on campus is unacceptable (35)

Influence of friend/acquaintances who aren't religious (36)

No longer find religion relevant to life (37)

Leadership is sexist (38)

Boring forms of worship and service (39)

Sermons are too spiritual. Lack of social responsibility dimension (40)

Sermons are too academic. Lack of spiritual dimension (41)

You are here primarily to study. Religion will be attended to at a later stage (42) 
43 Would you like to recommend any changes to your religious organisation? Yes, No, Not applicable

44 If yes, which of the following should be changed?

The current leadership (44)

Format of worship services (45)

Introduction of social programmes (46)

Organisation of intervarsity tours for interaction with groups in other universities (47)

Establishment of an inter-religion forum for periodic discussions (48)

Sensitivity about gender should be taken into account (49)

Pastoral guidance from local minister/pastor/priest/rabbi/imaam/mullah/ swami, etc (50)

Racial representativeness in the organisation (51)

52 What do you consider the most important purpose of religion?

To acknowledge that there is a God who needs to be worshipped

To give meaning to life

An opium for the masses

To provide guidelines for moral behaviour

To promote social interaction among people

Other (specify)

53 Does your religion / religious denomination allow its members to do the following?

Use of liquor (53)

Smoking of tobacco (54)

Visits to night clubs (55)

Smoking of dagga (marijuana) (56)

Participating in pre-marital sex (57)

Participating in homosexual relationships (58)

59 Regardless of what your religion / religious denomination teaches, do you personally participate in the following?

Taking alcoholic beverages (59)

Smoking of cigarettes, cigars, etc (60)

Pre-marital sex (61)

Gay/lesbian relationships (62)

Smoking of dagga (marijuana) (63) 
64 Does your religion/denomination teach a specific moral code of behaviour to which members must adhere? Yes, No, Not applicable

65 Do you consider the use of alcohol or tobacco as:

A right, for all citizens should have a choice of what they want

An inadequate action which ends in the degradation of morals

Not applicable

66 Do you have a boyfriend/girlfriend/lover? Yes, No

67 Are you sexually active? Yes, No, Not currently, It is a private matter

68 What is your opinion about religion in general?

69 What recommendations would you make with regard to student religiousness? 
APPENDIX 2: FULLTIME STUDENTS IN THE DIFFERENT UNIVERSITY OF PRETORIA FACULTIES, 2001, AND THE PROPOSED AND REAL SAMPLE SIZES

\begin{tabular}{|c|c|c|c|c|c|c|}
\hline FACULTY & SENIOR & RES. & SEX & POP. & $\begin{array}{l}\text { PROPOSED } \\
\text { SAMPLE }\end{array}$ & $\begin{array}{l}\text { REAL } \\
\text { SAMPLE }\end{array}$ \\
\hline HUMANITIES & $\begin{array}{l}\text { First } \\
\text { Senior }\end{array}$ & $\begin{array}{l}\text { Day } \\
\text { Day } \\
\text { UP } \\
\text { UP } \\
\text { Day } \\
\text { Day } \\
\text { UP } \\
\text { UP }\end{array}$ & $\begin{array}{l}\text { male } \\
\text { female } \\
\text { male } \\
\text { female } \\
\text { male } \\
\text { female } \\
\text { male } \\
\text { female } \\
\text { Total }\end{array}$ & $\begin{array}{l}260 \\
275 \\
145 \\
211 \\
1063 \\
1124 \\
594 \\
865 \\
4537 \\
\end{array}$ & $\begin{array}{l}15 \\
15 \\
11 \\
13 \\
31 \\
32 \\
23 \\
28 \\
168 \\
\end{array}$ & 154 \\
\hline AGRICULTURE & $\begin{array}{l}\text { First } \\
\text { Senior }\end{array}$ & $\begin{array}{l}\text { Day } \\
\text { Day } \\
\text { UP } \\
\text { UP } \\
\text { Day } \\
\text { Day } \\
\text { UP } \\
\text { UP }\end{array}$ & $\begin{array}{l}\text { Male } \\
\text { Female } \\
\text { Male } \\
\text { Female } \\
\text { Male } \\
\text { Female } \\
\text { Male } \\
\text { Female } \\
\text { Total }\end{array}$ & $\begin{array}{l}239 \\
253 \\
133 \\
194 \\
779 \\
824 \\
435 \\
634 \\
3491\end{array}$ & $\begin{array}{l}14 \\
15 \\
10 \\
13 \\
27 \\
27 \\
19 \\
24 \\
149\end{array}$ & $\begin{array}{r} \\
112 \\
112\end{array}$ \\
\hline LAW & $\begin{array}{l}\text { First } \\
\text { Senior }\end{array}$ & $\begin{array}{l}\text { Day } \\
\text { Day } \\
\text { UP } \\
\text { UP } \\
\text { Day } \\
\text { Day } \\
\text { UP } \\
\text { UP }\end{array}$ & $\begin{array}{l}\text { Male } \\
\text { Female } \\
\text { Male } \\
\text { Female } \\
\text { Male } \\
\text { Female } \\
\text { Male } \\
\text { Female } \\
\text { Total }\end{array}$ & $\begin{array}{l}80 \\
84 \\
44 \\
65 \\
533 \\
563 \\
297 \\
433 \\
2099\end{array}$ & $\begin{array}{l}10 \\
10 \\
10 \\
10 \\
22 \\
22 \\
16 \\
19 \\
119\end{array}$ & 84 \\
\hline THEOLOGY & $\begin{array}{l}\text { First } \\
\text { senior }\end{array}$ & $\begin{array}{l}\text { Day } \\
\text { Day } \\
\text { UP } \\
\text { UP }\end{array}$ & $\begin{array}{l}\text { Male } \\
\text { Female } \\
\text { Male } \\
\text { Female }\end{array}$ & $\begin{array}{l}8 \\
8 \\
4 \\
6\end{array}$ & $\begin{array}{l}10 \\
10 \\
10 \\
10\end{array}$ & \\
\hline
\end{tabular}




\begin{tabular}{|c|c|c|c|c|c|c|}
\hline & & $\begin{array}{l}\text { Day } \\
\text { Day } \\
\text { UP } \\
\text { UP }\end{array}$ & $\begin{array}{l}\text { Male } \\
\text { Female } \\
\text { Male } \\
\text { Female } \\
\text { Total } \\
\end{array}$ & $\begin{array}{l}102 \\
108 \\
57 \\
83 \\
376 \\
\end{array}$ & $\begin{array}{l}10 \\
10 \\
10 \\
10 \\
80 \\
\end{array}$ & 26 \\
\hline COMMERCE & $\begin{array}{l}\text { First } \\
\text { Senior }\end{array}$ & $\begin{array}{l}\text { Day } \\
\text { Day } \\
\text { UP } \\
\text { UP } \\
\text { Day } \\
\text { Day } \\
\text { UP } \\
\text { UP }\end{array}$ & $\begin{array}{l}\text { Male } \\
\text { Female } \\
\text { Male } \\
\text { Female } \\
\text { Male } \\
\text { Female } \\
\text { Male } \\
\text { Female } \\
\text { Total }\end{array}$ & $\begin{array}{l}448 \\
474 \\
250 \\
365 \\
1541 \\
1629 \\
860 \\
1253 \\
6820\end{array}$ & $\begin{array}{l}20 \\
20 \\
14 \\
18 \\
38 \\
39 \\
28 \\
34 \\
211\end{array}$ & 229 \\
\hline EDUCATION & $\begin{array}{l}\text { First } \\
\text { senior }\end{array}$ & $\begin{array}{l}\text { Day } \\
\text { Day } \\
\text { UP } \\
\text { UP } \\
\text { Day } \\
\text { Day } \\
\text { UP } \\
\text { UP }\end{array}$ & $\begin{array}{l}\text { Male } \\
\text { Female } \\
\text { Male } \\
\text { Female } \\
\text { Male } \\
\text { Female } \\
\text { Male } \\
\text { female } \\
\text { total } \\
\end{array}$ & $\begin{array}{l}120 \\
127 \\
67 \\
98 \\
574 \\
607 \\
321 \\
467 \\
2381 \\
\end{array}$ & $\begin{array}{l}10 \\
10 \\
10 \\
10 \\
23 \\
23 \\
17 \\
20 \\
123 \\
\end{array}$ & 7 \\
\hline ENGINEERING & $\begin{array}{l}\text { First } \\
\text { Senior }\end{array}$ & $\begin{array}{l}\text { Day } \\
\text { Day } \\
\text { UP } \\
\text { UP } \\
\text { Day } \\
\text { Day } \\
\text { UP } \\
\text { UP }\end{array}$ & $\begin{array}{l}\text { Male } \\
\text { Female } \\
\text { Male } \\
\text { Female } \\
\text { Male } \\
\text { Female } \\
\text { Male } \\
\text { Female } \\
\text { Total }\end{array}$ & $\begin{array}{l}177 \\
187 \\
99 \\
144 \\
914 \\
966 \\
510 \\
743 \\
3740\end{array}$ & $\begin{array}{l}12 \\
12 \\
10 \\
11 \\
29 \\
30 \\
21 \\
26 \\
151\end{array}$ & 134 \\
\hline TOTAL & & & & 23446 & 1001 & 739 \\
\hline
\end{tabular}

